\title{
DOI: https://doi.org/10.24297/ijmit.v14i0.7852
}

\section{The Role of Contextual Factors in Knowledge Transfer in Transactional Projects}

Fariba Shoeleh a* Mahmoud Golabchib Siamak haji Yakhchalic Nima Yazdanid

a PhD student, Department of Architecture, University of Tehran, Tehran, Iran

aEmail: fariba.shoeleh@ut.ac.ir

b Professor, Department of Architecture, University of Tehran, Tehran, Iran

bEmail: golabchi@ ut.ac.ir

${ }^{\mathrm{c}}$ Assistant Professor, Department of Industrial Engineering, University of Tehran, Tehran, Iran

cEmail: yakhchali@ut.ac.ir

d PhD student, Department of Architecture, University of Tehran, Tehran, Iran

dEmail: nyazdani88@ut.ac.ir

\begin{abstract}
Nowadays, with a significant growth in the number of organizations, they seeks to increase their competitive advantages as much as possible. One of the effective approaches is knowledge management, through which organizations try to reuse the experiences and knowledge created in their previous projects. Today, many projects are carried out by forces from other nationalities, in which each participating organization operates within complex national, organizational, and information contexts. So, knowledge is transferred between geographically dispersed individuals and organizations, and across cultural and national boundaries. Given these conditions, knowledge management processes, especially the transfer and acquisition of knowledge, are very important. The purpose of the present study is to design a conceptual framework of the contextual factors affecting the knowledge transfer in transnational projects using meta-synthesis method. For this purpose, firstly the previous research has been studied and interpreted the factors which are effective in transferring knowledge from different sources and then analyzed them using the open coding method to propose a conceptual framework
\end{abstract}

Indexing terms/Keywords:Knowledge; Knowledge Transfer; Contextual Factors; Meta Synthesis; Transnational Projects

Language : English

Date of Submission : 2018-10-13

Date of Acceptance : 2018-10-23

Date of Publication : 2018-11-08

DOI 10.24297/ijmit.v14i0.7852

ISSN : 2278-5612

Volume : 14 Issue

Journal : INTENATIONAL JOURNAL OF MANAGEMENT AND INFORMATION TECHNOLOGY

Publisher : CIRWORLD

Website : https://cirworld.com

This work is licensed under a Creative Commons Attribution 4.0 International License. 


\section{Introduction}

As rich sources of knowledge, projects can build up organizations' competency and therefore be more effectiveness if they are able to transfer their generated knowledge to other organizations and projects. Since the risk of losing project knowledge often remains even after project completion and has taken off as a subject in some studies. A number of studies lay emphasis on the acquisition and sharing of knowledge project so as to mitigate the risk [1, 2, 3, and 4]. Although organization's projects are considered temporary, they are often viewed as efficient means of combining knowledge, and thus optimizing the amount ofinvestment [5].

With increasing uncertainties, time constraints and higher quality requirements in projects, the complexity of projects has increased, which has made projects knowledge management a success key factor. Organizations are required to provide a setting for knowledge sharing, transferring and exchanging among their members, train them to make sense of their interaction, and lay the foundations for the recognition of contextual factors in the deployment of knowledge management in organization [6]. In today's world, with the increasing complexity of projects in all industries, carrying out each project requires a high level of knowledge and expertise, which some countries, particularly developing countries seem unable to get them off their ground, despite their essential foundations within their borders. In an increasingly globalized world, there is a need for companies to go cross-border. The current focus is not only on the home market but also to a great degree abroad, thus a company reaches a much larger market [7]. Today, various types of international contracts are signed and organizations start projects beyond their own borders without a mutual nationality.

Implementing a project outside of organization's borders brings it a lot of competitive advantages. In addition to this, the host country benefits from parent company's knowledge and expertise in an attempt to promote its infrastructure and build up its technical and managerial knowledge. Knowledge transfer is achieved between two individuals, i.e. sender and receiver; the role of sender just like receiver can be assumed by an individual or a group [8]. Author in [9] maintain that knowledge is today shared among individuals and organizations dispersed geographically and situated at various cultural and national boundaries. Firms with geo-graphically dispersed operations face the fundamental challenge of dealing with myriad country differences, including regulations, cultures, and institutions [10]. A study conducted by Shokri-Ghasabeh and Chileshe [11] in project-based organizations deals with obstacles and potentials in an effort to learn from other projects. The importance of geo-graphic proximity for knowledge sharing has been discussed extensively in recent years [12].

There are plenty of gaps in our understanding of transnational knowledge transfer. In the literature of knowledge transfer, such factors as culture, organizational structure, language and other related components that affect the process of knowledge transfer are extremely important, which is why the present research aims to identify and explore these contextual factors so as to provide a consistent and comprehensive vision of these factors, which can be used for the progress of national organizations. The purpose of the present research is to identify and classify contextual factors affecting transnational knowledge transfer in a comprehensive and coherent framework. To this end, a meta-synthesis method was used to compare, interpret, convert and combine various frameworks. This method discovers subjects and offers a new categorization by combining previous studies.

The paper is organized as follows: in the next section, the previous work on knowledge management and also transnational knowledge transfer are reviewed. Section 3 describes our research methodology. In Section 4 , the data analysis and our proposed qualitative meta-synthesis procedure consisting of seven main steps is explained. Section 5 lists and classifies all obtained effective factors and presents our comprehensive framework. Finally, the paper is concluded in Section 6.

\section{Literature Review}

\section{Knowledge Management}

There is no specific definition available for knowledge despite its popularity. In 2008, Koskinen and Philanto defined knowledge as an individual's perception, skills and experience, which are typical what experiences the person's perspective contains in the form of meanings [13]. They underlined one important aspect of knowledge, which is the dependency on the personal and social context an individual is embedded in [14].

The process of knowledge management can be achieved between two organizations, from outside of an organization to the inside, or between internal departments of an organization, i.e. organizational units. 
Technical infrastructure plays a central role in intra-organizational knowledge transfer as it allows employees to codify, store and access knowledge [15]. If an organization is able to provide necessary infrastructures for knowledge transfer between organizational units, the way for attracting knowledge from outside of organization will be to a great extent provided. Given the review of the literature, it was revealed that the two concepts namely knowledge transfer and knowledge sharing encompass close definitions, inasmuch as they are even used interchangeably in some cases.

In literature, the term of knowledge sharing is associated with other knowledge process such as knowledge flow, transfer, learning, creation, and distributed collaboration [16]. Knowledge sharing is a set of behaviors that include knowledge and information exchange and provide assistance to others in this regard. Author in[17] states that knowledge sharing is achieved voluntarily in organizations. One of the methods of measuring knowledge management is to measure the amount of knowledge sharing (i.e. explicit and implicit knowledge), which is followed in organizations. Whereas knowledge transfer occurs at higher level. It typically has been used to describe how knowledge can exchange between different units, divisions, or organizations rather than individuals [18]. In the words of Hofer [19], knowledge transfer includes focused and one-way relocation between individuals, groups and organizations in such a way that receiver of knowledge has (a) a cognitive understanding, (b) the ability to operate it, or (c) applies the knowledge.

If we want people to share what they learn in organization, some conditions must be met, in which the result of sharing should have individual advantage. Authors in [20] state that the event through which an organization learns the knowledge and experience of other organizations is referred to as inter-organizational knowledge transfer or inter-organizational learning. By knowledge transfer, we mean a boost in organization's ability to do works, thereby building up its value. In general, the richer and more intangible knowledge is, the more technologies one must utilize to transfer it, is needed. However, values, norms, and behaviors that embody the culture of a corporation are main determinants of knowledge transfer success. The main determinant of success in any knowledge transfer project is the creation of a common language among colleagues. Authors in [9] believe that factors contributing to knowledge transfer in project-based organizations and facilitating it are as follows, though they are not constrained by them:

- Actors; problems associated with culture, motivation, knowledge distance, trust between team members.

- Context; problems associated with inter-organization relations, appropriate partner selection and flexibility of organizations.

- Content; problems associated with goals, focus, and the nature of knowledge to be transferred

- Medium; e.g. language

\section{Transactional Knowledge Transfer}

As stated above, the main purpose of this research is effective knowledge transfer in the environment of projects and specifically focuses on transnational projects. Given the definition by the book named "A Guide to the Project Management Body of Knowledge" [21], project is a temporary endeavor undertaken to create a unique product or service, or a unique result. The nature of projects represents a definite end and start. It is an internal contract when signed and implemented within the borders of a country, but international and transnational term refers to parties to a con-tract traded beyond borders, or it is stipulated that the contract be executed beyond boundaries.

Govindarajan and Gupta [22] state that a transnational project is a project in that organizational unit is temporarily set beyond boundaries, and individuals with different expert and knowledge come together to deal with a common global task. The transnational projects have also the challenge of a diverse group of people from different nationalities who work together for a limited period of time to accomplish a specific project goal [23]. In this research, by transnational projects, we mean those projects where one of the main elements of the project is the host abroad, so project team is comprised of different nations with different languages and cultures who came together to achieve a single purpose. Mei et al. considered the competence, culture, resource, strategy, and organization relationship as the main influencing factors to analyze the project management knowledge transferring [24]. 


\section{Research Methodology}

The quality of a scientific research rests on research purpose, the choice of a good method, and observance of scientific research principles. The research method of this study is meta-synthesis. This method is used to identify the contextual factors for transnational knowledge transfer in or-der to integrate several studies in order to design a comprehensive and interpretive framework. The existing articles about knowledge transfer come in two forms of qualitative and quantitative. Hence meta-synthesis is a method geared to achieve a comprehensive synthesis of this subject based on translation of qualitative studies and results of quantitative studies. Providing a systematic perspective for researchers through combining different studies, metasynthesis explores new and fundamental themes. By doing so, it builds up the existing knowledge and comes up with a thorough perspective on issues. Sandelowski and Barroso in [25] proposed a seven-step method which is used in this research.

\section{Meta Synthesis Procedure}

In our meta-synthesis study, we followed the seven-step meta-ethnography approach proposed by Sandelowski and Barroso [25]. The steps of this approach are outlined in Fig 1.

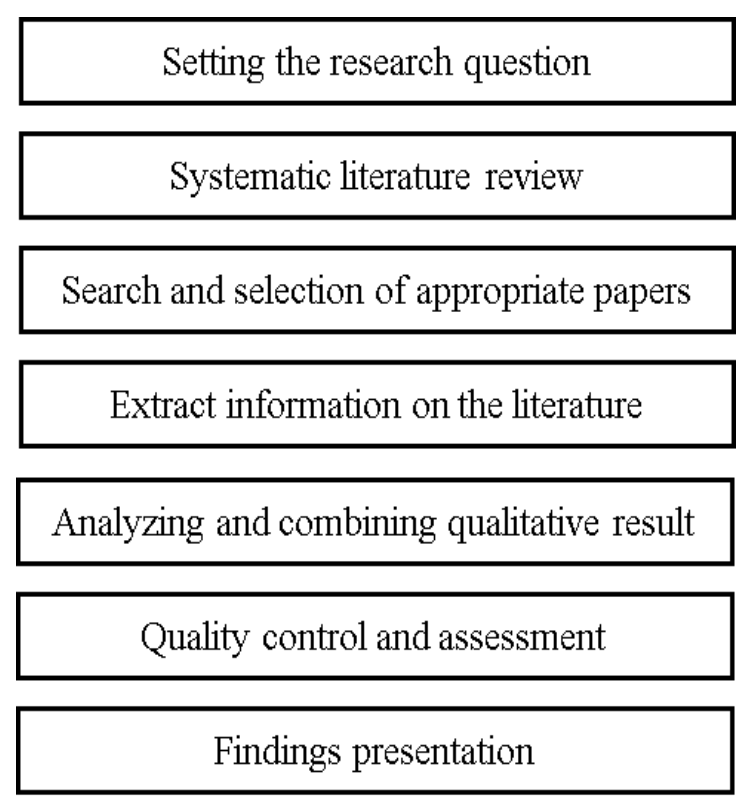

Figure 1:Meta-Synthesis Steps

\subsection{Step 1: Identifying the research question}

A question or a goal must first be designed for each research activity. To set this question, the first step is to specify "what". In this research, identifying the contextual factors in transferring knowledge in transnational projects is examined. In the next step, the question "Who" indicates the community under investigation, which explores databases and journals in this research. In the next step, the question "When" defines the time frame for the reviewed articles. In this study, studies are conducted between 2002 and 2018. The final question is the word "How" that is the method used to compile the research data. To collect data, all research (including research and review) has been used in the field of transnational knowledge transfer. According to the stated questions, the research question to follow the next steps is as follows:

- What are the contextual factors in knowledge transfer in transnational projects from 2002 to 2018 ? How can these factors be categorized? 
Table 1:Relevant keywords

\begin{tabular}{|l|l|}
\hline Keywords & Electronic Databases \\
\hline Knowledge Transfer & Emerald \\
Knowledge Sharing & $\begin{array}{l}\text { ScienceDirect } \\
\text { (Elsevier) }\end{array}$ \\
Contextual Factors & IEEE \\
Projects & Springer \\
International & ProQuest \\
Transnational & Emerald \\
\hline
\end{tabular}

\subsection{Step 2: Identifying literature relevant to the research question in a systematic way}

In this step, in order to systematically search for articles published in different journals, relevant key words should be defined. In order to answer the first step questions, the terms listed in Table 1 are considered.

\subsection{Search and select the relevant studies}

At this stage with several reviews, a number of articles are rejected and are not being examined in the process. The review process is briefly summarized in figure 2. Using the Critical appraisal skills program (CASP), the quality of researches can be assessed. In this method, 10 questions can be used to determine the accuracy, validity and importance of the studies. These questions include the following: : 1) Research objectives, 2) Logic of method, 3) Research design, 4) Sampling method, 5) Data collection, 6) Reflectivity, 7) Moral considerations, 8) Data analysis, 9) Clear expression of the results, and 10) Research significance. At this stage, the researcher gives a points to each of these questions, and then creates a form. So, he can add points that are given to each article and easily and briefly review articles and see the results of the evaluation. Finally, the researcher based on a 50-option Rubik scale (listed in Table 2) scores and excludes papers with a score below the good score [26].

Table 2:Rubik 50 points scale

\begin{tabular}{llll}
\hline Score & Abbreviation & Definition & Procedure \\
\hline $40-50$ & VG & Very Good & Accepted \\
$31-40$ & G & Good & Accepted \\
$21-30$ & M & Moderate & Accepted \\
$11-20$ & W & Weak & Rejected \\
\hline
\end{tabular}




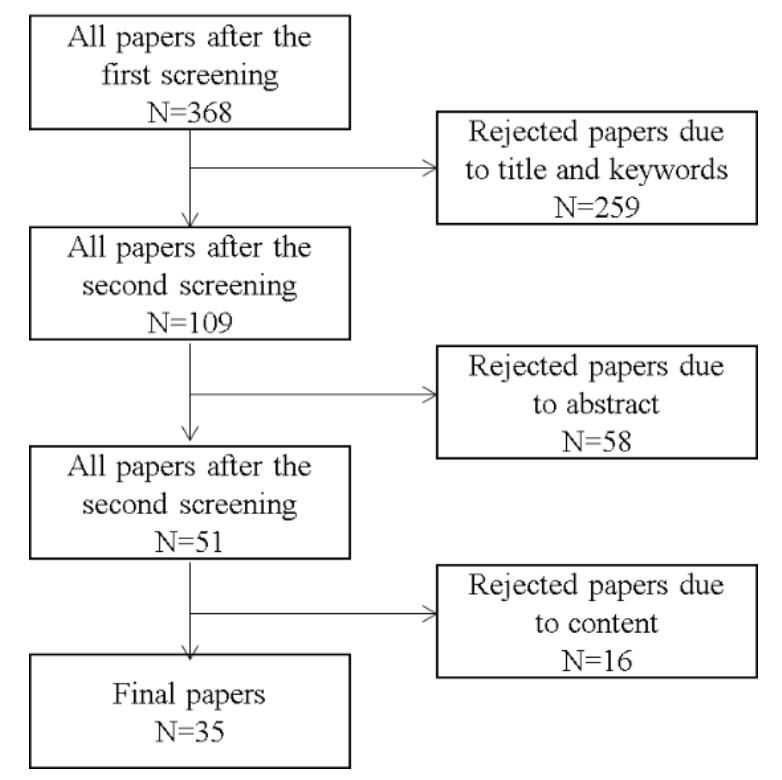

Figure 2:Review Process for Selecting the Intended Papers

Fig. 2 illustrates the review process for selecting the Intended articles. After reviewing articles and rating them, 3 very good papers, 15 good papers and 17 moderate articles were evaluated. In this step, articles whose results are not usable or trustworthy were omitted. In sum, 35 papers were selected as Intended papers.

\subsection{Data extraction}

In the extract section, the results of the article's information are classified according to the reference for each article, including the full name of the author, along with the year of publication of the article and the components of the coordination expressed in each article. In this step, final articles were studied using content analysis. Content analysis is an accurate study of resources and documents which is used to examine the explicit content as well as the deeper layers of the hidden documents. The results obtained from this step are shown in Table 3.

Table 3:Knowledge transfer factors extracted from selected sources

\begin{tabular}{|l|l|l|}
\hline Authors & Year & Knowledge Transfer Factors \\
\hline $\begin{array}{l}\text { Dawes et al. } \\
\text { [27] }\end{array}$ & 2012 & $\begin{array}{l}\text { Define factors into three categories: 1) Knowledge and information context 2) } \\
\text { Organizational context 3) National context }\end{array}$ \\
\hline $\begin{array}{l}\text { Adenfelt \& } \\
\text { Lagerström } \\
\text { [28] }\end{array}$ & 2006 & $\begin{array}{l}\text { There are two main categories for knowledge transfer in transnational } \\
\text { projects: 1) Social (organizational culture, structure and individuals) and 2) } \\
\text { Technological (communication technology and support) }\end{array}$ \\
\hline $\begin{array}{l}\text { Schomaker } \\
\text { \& Zaheer } \\
\text { [10] }\end{array}$ & 2014 & $\begin{array}{l}\text { The Impact of Language on Knowledge Transfer in Scattered Geographic } \\
\text { Units }\end{array}$ \\
\hline $\begin{array}{l}\text { Ambos \& } \\
\text { Ambos [15] }\end{array}$ & 2009 & $\begin{array}{l}\text { Investigating the Impact of Different Dimensions in personal coordination } \\
\text { mechanisms and technology-based coordination mechanisms in Knowledge } \\
\text { Transfer. There are three types of distinction: (1-spatial, 2-cultural and 3- } \\
\text { linguistic). }\end{array}$ \\
\hline $\begin{array}{l}\text { Duan et al. } \\
\text { [9] }\end{array}$ & 2010 & $\begin{array}{l}\text { Determination of factors in four main categories: 1) actors 2) context 3) } \\
\text { Content 4) media }\end{array}$ \\
\hline
\end{tabular}




\begin{tabular}{|c|c|c|}
\hline $\begin{array}{l}\text { Makela et al. } \\
\text { [29] }\end{array}$ & 2007 & $\begin{array}{l}\text { Individual similarities play an important role in knowledge sharing, including } \\
\text { the context of national cultural back ground, common language and the same } \\
\text { organizational status. }\end{array}$ \\
\hline $\begin{array}{l}\text { Jasimuddin } \\
\text { et al. [30] }\end{array}$ & 2015 & $\begin{array}{l}\text { Investigating the role of geographical distance in knowledge transfer, } \\
\text { investigating the role of geographical distance in cultural distance and } \\
\text { communication distance and consequently its impact on knowledge transfer. }\end{array}$ \\
\hline $\begin{array}{l}\text { Bengoa et } \\
\text { al. [31] }\end{array}$ & 2015 & $\begin{array}{l}\text { Investigating the factors that influence the transfer of knowledge, the } \\
\text { identified factors are: (knowledge content, skills, motivation, national culture, } \\
\text { organization culture, strategy, infrastructure and resources) }\end{array}$ \\
\hline $\begin{array}{l}\text { Nordtvedt et } \\
\text { al. [32] }\end{array}$ & 2008 & $\begin{array}{l}\text { Investigating the Effectiveness of Knowledge Transfer across Borders, } \\
\text { Dividing Knowledge characteristics: } 1 . \text { Valuable Knowledge } 2 \text {. Rare } \\
\text { Knowledge } 3 . \quad \text { Inimitable Knowledge } 4 . \quad \text { Non-suitable Knowledge- } \\
\text { (comprehension-usefulness) reflecting knowledge transfer effectiveness and } \\
\text { ( Speed - Economy) reflecting Knowledge Transfer efficiency- Effective } \\
\text { Factors: 1- relationship Quality 2- Sources attractiveness 3- recipient learning } \\
\text { intent }\end{array}$ \\
\hline $\begin{array}{l}\text { Fletcher- } \\
\text { Chen [33] }\end{array}$ & 2015 & $\begin{array}{l}\text { Impact of language diversity and social interaction Knowledge transfer, the } \\
\text { definition of two important dimensions includes: communication (discussion } \\
\text { quality- richness-openness-accuracy) absorption capacity (assessment- } \\
\text { Assimilation - Application.) }\end{array}$ \\
\hline $\begin{array}{l}\text { Ford \& Chan } \\
\text { [34] }\end{array}$ & 2003 & $\begin{array}{l}\text { The study of culture based on Hofsted's cultural dimensions (power distance, } \\
\text { collective or individualism, avoidance of uncertainty, gender, long-term } \\
\text { orientation), barriers to knowledge sharing: language, time and resources } \\
\text { constraints, lack of structure and rewards, power and job security, Lack of } \\
\text { proper social networking) }\end{array}$ \\
\hline Ahmad [35] & 2017 & $\begin{array}{l}\text { Transfer of knowledge in different language areas - Examining the } \\
\text { challenges posed by non-native losses include: 1) ambiguity 2) cost - which } \\
\text { suggests three strategies: setting the discourse-setting the transmission } \\
\text { device-language setting }\end{array}$ \\
\hline $\begin{array}{l}\text { Fong Boh et } \\
\text { al. [36] }\end{array}$ & 2013 & $\begin{array}{l}\text { Influencing factors in the transfer of knowledge when the parties have no } \\
\text { common national culture: } 1 \text { - Trust 2- Cultural identity of individualism 3- } \\
\text { Cultural-cultural parallelism 4- Distribution-openness to diversity }\end{array}$ \\
\hline $\begin{array}{l}\text { Ismail et al. } \\
\text { [37] }\end{array}$ & 2016 & $\begin{array}{l}\text { Investigating the individual and social factors in the transfer of knowledge - } \\
\text { the division of individual factors into (cultural intelligence and behavioral } \\
\text { feedback requests) social factors (common vision - trust) - according to the } \\
\text { research the most important factors are: } 1 \text {. Common perspectives } 2 \text { - Trust } 3 \text {. } \\
\text { Intelligence Cultural and feedback - this research shows that social factors } \\
\text { are more influential }\end{array}$ \\
\hline $\begin{array}{l}\text { Dobrai et al. } \\
\text { [38] }\end{array}$ & 2012 & $\begin{array}{l}\text { Categorization of factors into three categories: } 1 \text { - Individual and group level } \\
\text { 2- Organizational level 3. Global level - Expression of knowledge transfer } \\
\text { factors including: ability to transfer 2- Transfer motivation 3- Transfer method } \\
\text { 4- Knowledge type. }\end{array}$ \\
\hline Pablos [39] & 2006 & $\begin{array}{l}\text { Definition of mental assets is divided into four categories: 1. Human Capital; } \\
\text { 2. relational Capital; 3. Organizational Capital; 4. Technology Capital; } \\
\text { Definition of Knowledge Based on Strategic and Negative Value in Four } \\
\text { Areas: (Sub-Compulsory-Special-Core) - Determining the factors that have a } \\
\text { negative impact on the transfer of knowledge (implicitly - social complexity - } \\
\text { causality ambiguity - the distance between organizational culture and the }\end{array}$ \\
\hline
\end{tabular}




\begin{tabular}{|l|l|l|}
\hline & & distance between national culture) \\
\hline $\begin{array}{l}\text { Killingsworth } \\
\text { et al [40] }\end{array}$ & 2016 & $\begin{array}{l}\text { The factors that affect the sharing of knowledge are the attitude that affects } \\
\text { the knowledge sharing of individuals. Attitude is dependent on two factors: } \\
\text { (team environment: 1- dependence; 2- trust); (motivation: external: mutual } \\
\text { benefit; internal motivation: pleasure); - the study found that affiliation does } \\
\text { not affect the attitude for knowledge sharing behaviors }\end{array}$ \\
\hline $\begin{array}{l}\text { Vuori \& } \\
\text { Okkonen[41] }\end{array}$ & 2012 & $\begin{array}{l}\text { Investigating the motivational factors that affect the sharing of knowledge } \\
\text { within the organization with the mass media. }\end{array}$ \\
\hline
\end{tabular}

\subsection{Analysis and combining the findings}

Here, the analysis and integration of findings have been done through open coding. At first, we consider all the factors extracted from the studies as codes, then, by considering the meaning of each of these codes, we classify them in the same sense. In this way, we formulate research concepts. In Table 4, the factors are briefly shown.

\subsection{Quality control and assessment}

In this research, an attempt was made to take out articles from journals and valid databases, and articles with inadequate scientific credibility were excluded from the process of synthesis. To combine main studies, using CASP tool, the quality degree of the articles was assessed. Moreover, in this research in an effort to maintain the quality of the study, Kappa index was used, which will be introduced in the next section.

\subsection{Finding presentation}

Having completed the processes of meta-synthesis, a framework for contextual factors affecting transfer of transnational knowledge consisting of two layers (criteria and factors) was developed; Table 5 has shown these criteria.

Table 4:The Codes and references of contextual factors affecting knowledge transfer

\begin{tabular}{|c|c|c|}
\hline Concepts & Codes & Recent References \\
\hline \multirow{5}{*}{$\begin{array}{l}\text { Contextual } \\
\text { Factors }\end{array}$} & Language & $\begin{array}{l}\text { Sunaoshi et. al. (2005) [42], Kayes et. al. (2005) [43], Makela et. al. } \\
\text { (2007) [29], Welch and Welch (2008) [44], Ambos and Ambos } \\
\text { (2009) [15], Schomaker and Zaheer (2014) [10], Fletcher-Chen } \\
\text { (2015)[33], Ahmad (2017) [35] }\end{array}$ \\
\hline & Cultural distance & $\begin{array}{l}\text { Dawes et. al. (2012) [27], Adenfelt and Lagerstrom (2006) [28], } \\
\text { Ambos and Ambos (2009) [15], Duan et. al.(2010) [9], Makela et. } \\
\text { al. (2007) [29], Jasimuddin et. al. (2015) [30], Bengoa et al. (2015) } \\
\text { [31],Fong Boh et,al.(2013) [36], Pablos (2006) [39], Vuori and } \\
\text { Okkonen (2012) [41], Welch and Welch (2008) [44], Gang and } \\
\text { Bosen (2010) [45],Raab et. al. (2014) [46] }\end{array}$ \\
\hline & $\begin{array}{l}\text { Geographical } \\
\text { distance }\end{array}$ & $\begin{array}{l}\text { Hansen and Lovas (2004) [47], Jonsson and Kalling (2007) [48], } \\
\text { Ambos and Amb (2009) [15], Ganga and Bosen (2010) [45], Chan } \\
\text { et. al. (2010) [49], Raab et. al. (2014) [46], Jasimuddin et. al. } \\
\text { (2015) [30], Dawes et. al. (2012) [27], Duan et. al.(2010) [9] }\end{array}$ \\
\hline & Time zone & Gang and Bosen (2010) [45] \\
\hline & $\begin{array}{l}\text { Relational } \\
\text { distance }\end{array}$ & $\begin{array}{l}\text { Dawes et. al. (2012) [27], Duan et. al.(2010) [9], Jasimuddin et. al. } \\
\text { (2015) [30], Gang and Bosen (2010) [45], Fletcher-Chen (2015) [33], } \\
\text { Pérez-Nordtvedt et. al. (2008) [32] }\end{array}$ \\
\hline
\end{tabular}




\begin{tabular}{|l|l|}
\hline $\begin{array}{l}\text { Policies and } \\
\text { laws }\end{array}$ & Duan et. al.(2010) [9]. \\
\hline $\begin{array}{l}\text { Technical } \\
\text { distance }\end{array}$ & $\begin{array}{l}\text { Duan et. al. (2010) [9], Dawes et. al. (2012) [27], Adenfelt and } \\
\text { Lagerstrom (2005) [28], Makela et al. (2007) [29], Bengoa et al. } \\
\text { (2015) [31] }\end{array}$ \\
\hline $\begin{array}{l}\text { Knowledge } \\
\text { distance }\end{array}$ & $\begin{array}{l}\text { Duan et. al.(2010) [9], Dawes et. al. (2012) [27], Bengoa et al. } \\
\text { (2015) [31],Pérez-Nordtvedt et. al. (2008) [32] }\end{array}$ \\
\hline $\begin{array}{l}\text { Organizational } \\
\text { distance }\end{array}$ & $\begin{array}{l}\text { Dawes et. al. (2012) [27], Bengoa et al. (2015) [31], Makela et. al. } \\
\text { (2007) [29], Ismail et, al.(2016) [37], Pablos (2006) [39], } \\
\text { Killingsworth et. al. (2016) [40] }\end{array}$ \\
\hline $\begin{array}{l}\text { Intention } \\
\text { distance }\end{array}$ & Dawes et. al. (2012) [27]. \\
\hline
\end{tabular}

Table 5: The breakdown structure of contextual factors affecting knowledge transfer.

\begin{tabular}{|c|c|c|}
\hline Concepts & Codes & Criteria \\
\hline \multirow{13}{*}{ Factors } & \multirow{5}{*}{ Language } & Definition of common language for ease of communication \\
\hline & & The close proximity of the parties makes it easy to communicate \\
\hline & & Language diversity increases the quality of discussions. \\
\hline & & $\begin{array}{l}\text { The use of technical words and the use of language media in cases } \\
\text { of use }\end{array}$ \\
\hline & & $\begin{array}{l}\text { Language policy (simplification of words and relaxation speed } \\
\text { communications) and confirming questions in cases of ambiguity }\end{array}$ \\
\hline & \multirow{5}{*}{$\begin{array}{l}\text { Cultural } \\
\text { distance }\end{array}$} & differences in culture make a difference in perceptions of people \\
\hline & & $\begin{array}{l}\text { The existence of team-mates with common culture increases the } \\
\text { eagerness of the knowledge process }\end{array}$ \\
\hline & & $\begin{array}{l}\text { The common background of national culture, beliefs, values, } \\
\text { perceptions and common practices is effective in the amount of } \\
\text { transmission. }\end{array}$ \\
\hline & & $\begin{array}{l}\text { The degree of difference between the views of the individual in terms } \\
\text { of individualism or group-based vision of organizational power }\end{array}$ \\
\hline & & The importance of trying to align cultures \\
\hline & \multirow[t]{3}{*}{$\begin{array}{l}\text { Geographical } \\
\text { distance }\end{array}$} & $\begin{array}{l}\text { The existence of the spatial distance affects the knowledge transfer } \\
\text { process }\end{array}$ \\
\hline & & $\begin{array}{l}\text { The spatial distance between knowledge exchanges is prevented by } \\
\text { staff and, in the event of long-time interaction, the transmission is } \\
\text { discouraging. }\end{array}$ \\
\hline & & Distance creates distrust and enthusiasm for the knowledge transfer \\
\hline
\end{tabular}




\begin{tabular}{|c|c|}
\hline Time zone & The difference in time makes it difficult to interact \\
\hline \multirow{2}{*}{$\begin{array}{l}\text { Relational } \\
\text { distance }\end{array}$} & Time and rate of previous interactions of individuals in the transfer \\
\hline & $\begin{array}{l}\text { It is more difficult to connect in the first time, and the duration of the } \\
\text { collaboration creates more relationships }\end{array}$ \\
\hline \multirow[t]{3}{*}{$\begin{array}{l}\text { Policies and } \\
\text { laws }\end{array}$} & $\begin{array}{l}\text { The existence of intellectual property in the production of knowledge } \\
\text { and privacy protection laws }\end{array}$ \\
\hline & $\begin{array}{l}\text { The lack of sufficient legal frameworks in contracts and the existence } \\
\text { of limiting regulatory infrastructures }\end{array}$ \\
\hline & $\begin{array}{l}\text { Ineffective implementation and frequent changes in the legal } \\
\text { infrastructure }\end{array}$ \\
\hline \multirow[t]{3}{*}{$\begin{array}{l}\text { Technical } \\
\text { distance }\end{array}$} & $\begin{array}{l}\text { Differences in IT infrastructure and technical knowledge of the parties } \\
\text { affect the knowledge transfer process }\end{array}$ \\
\hline & $\begin{array}{l}\text { The complexity of the infrastructure (due to differences in software } \\
\text { and hardware and data) in the course of knowledge transfer }\end{array}$ \\
\hline & Program and infrastructure standardization \\
\hline \multirow[t]{2}{*}{$\begin{array}{l}\text { Knowledge } \\
\text { distance }\end{array}$} & $\begin{array}{l}\text { The distance between knowledge (the difference between the current } \\
\text { knowledge of the two sides of the project) influences the learning } \\
\text { process }\end{array}$ \\
\hline & $\begin{array}{l}\text { If there is a common knowledge base, the transfer of surplus } \\
\text { knowledge is easier }\end{array}$ \\
\hline \multirow[t]{3}{*}{$\begin{array}{l}\text { Organizational } \\
\text { distance }\end{array}$} & $\begin{array}{l}\text { Degree of lack of solidarity and cultural difference between project } \\
\text { partners }\end{array}$ \\
\hline & $\begin{array}{l}\text { Differences in values, structure and trends in the organization of the } \\
\text { parties }\end{array}$ \\
\hline & Differences in goals and how organizations decide \\
\hline \multirow{3}{*}{$\begin{array}{l}\text { Intention } \\
\text { distance }\end{array}$} & Differences in missions and goals of organizations \\
\hline & The mutual benefits of the transfer process are difficult for the parties \\
\hline & Defining Guiding and Control Mechanisms for Knowledge Transfer \\
\hline
\end{tabular}

1.8. Validity and Reliability of the Model

In this research, the researcher took advantage of a comparison between her opinions and another expert's in order to control for elicited concepts. In doing so, two-coders' agreement was used, in that in addition to the researcher formulated a primary coding another researcher separately laid down codes for the same text coded by the researcher without knowing his codes; if the codes of the two researchers are similar, it shows a broad agreement between these two coders and indicates reliability. To calculate the coefficient of two coders' agreement, Cohen's kappa coefficient was used; how this index is calculated is shown by Formula (1).

In this study (in addition to CASP) another method has been used for assessing the quality of the content. In this paper, the researcher took advantage of a comparison between her opinions and another expert's in order to control for elicited concepts. To achieve this, a number of selected literatures were provided to an expert in the knowledge management without the knowledge of how to combine codes and concepts created by researchers to classify codes in categories separately. Then, presented categories by researchers were 
compared with presented categories by the person. And finally regarding similar and different categories of the researcher and expert, Kappa indicator has been calculated that indicates the reliability of the above. The indicator calculation has been provided in Equation 1. As seen in Table 6, researchers have created 10 categories and an-other expert has created 11 categories, of which 9 categories are common. As shown below, Kappa Indicator value is equal to 0.74 that according to Table 6 the value is at the level of the valid agreement.

- The number of selected samples by researcher: 10

- The number of selected categories by expert: 11

- The number of common selected categories: 9

Table 6:Crossing by the researcher and the expert

\begin{tabular}{|l|lll|}
\hline Score & \multicolumn{3}{|c|}{ Researcher View } \\
\hline Expert View & Yes & No & Total \\
\hline Yes & $\mathrm{A}=9$ & $\mathrm{~B}=2$ & 11 \\
No & $\mathrm{C}=1$ & $\mathrm{D}=0$ & 1 \\
Total & 10 & 2 & 12 \\
\hline
\end{tabular}

abserved agrement $=\frac{\cdots \cdots}{\mathrm{nr}}=\frac{\cdots \alpha}{1 \mathrm{n}}=0.75$

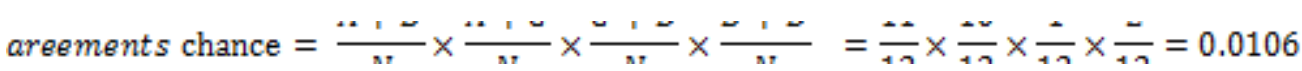

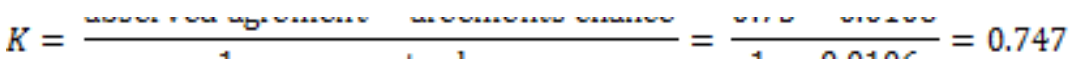

As can be shown in what follows, Kappa index was estimated to be 0.74 , which shows a valid consensus according to Table 7 .

Table 7:Kappa Indicator condition

\begin{tabular}{ll}
\hline Status Agreement & Numerical Value of Kappa Indicator \\
\hline Poor & Less than zero \\
Unimportant & Between $0-0.2$ \\
Fair & Between $0.21-0.4$ \\
Good & Between $0.41-0.6$ \\
Valid & Between $0.61-0.8$ \\
Excellent & Between $0.81-1$
\end{tabular}

In this research, using meta-synthesis method, these factors were elicited from the literature and a framework consisting of two layers (criteria and factors) were presented in three coding steps, in that a number of 10 factors were set. Given elicited factors, Fig. 3 represents a conceptual framework designed based on contextual factors in knowledge transfer in transnational projects. 


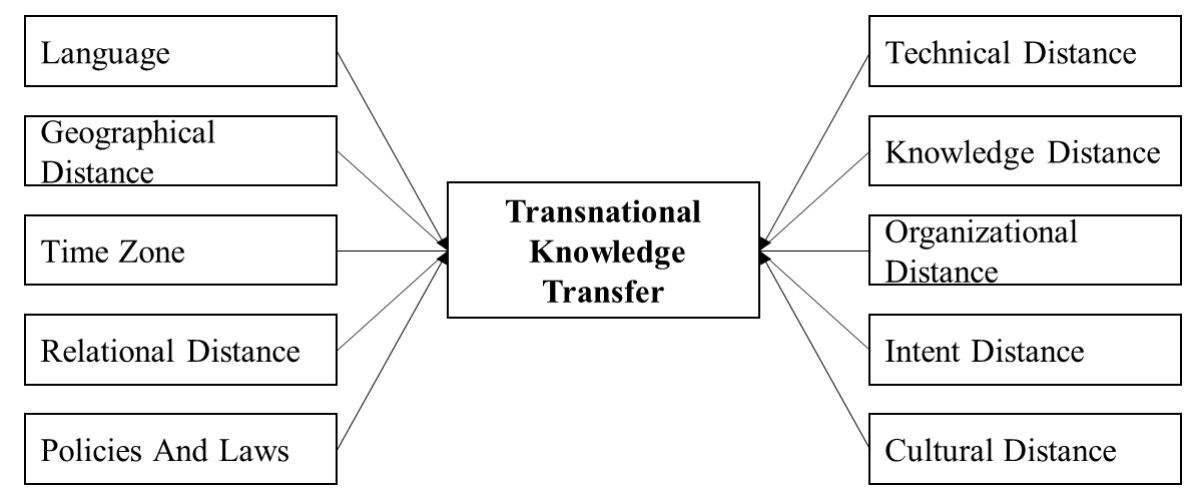

Figure 3:A framework of contextual factors affecting knowledge transfer in transnational projects

\section{Conclusion}

Following a review of studied conducted on knowledge transfer, it was revealed that various researchers individually introduce the impact on knowledge transfer by laying emphasis on a special factor; that is, some researcher underline language, culture, and organizational distances, while others deal with other aspects of transfer. Some researchers study factors like technical distance [27, 28, 9, 29, 31], which suggests that process of transfer would be difficult in the face of a great difference in technical infrastructures of parties involved in a project. Some articles by [27, 9, 31, 32] deal with knowledge distance, in that it suggests that individuals' knowledge level is of high significance for knowledge transfer, and in case of almost equal level of knowledge, the process of transfer and acquisition of surplus knowledge would be easier. Among studies done in this area, most of them dealt with a limited number of influential factors and none provided a comprehensive list of influential factors under transnational project circumstances. One of the aspects of the difference between the present research and other related studies is the presentation of a thorough framework with factors other than transfer of transnational knowledge compared to previous studies.

\section{References}

1. Lee, S., Park, J. G., \& Lee, J. "Explaining knowledge sharing with social capital theory in information systems development projects". Industrial Management \& Data Systems, vol. 115(5), pp. 883-900, 2015.

2. Almeida, M. V., \& Soares, A. L. "Knowledge sharing in project-based organizations: Overcoming the informational limbo". International Journal of Information Management, vol. 34(6), pp. 770-779, 2014.

3. Wang, J., \& Zhai, Y. "Knowledge Transfer in Equipment Acquisition Project". International Conference on Information Technology, Computer Engineering and Management Sciences (ICM), vol. 4, pp. 93-95, IEEE. 2011.

4. Wickramasinghe, V., \& Widyaratne, R. "Effects of interpersonal trust, team leader support, rewards, and knowledge sharing mechanisms on knowledge sharing in project teams". Vine, vol. 42(2), pp. 214-236, 2012.

5. Pemsel, S., \& Wiewiora, A. "Project management office a knowledge broker in project-based organisations". International Journal of Project Management, vol. 31(1), pp. 31-42, 2013.

6. Balogun, O., Hawisa, H., \& Tannock, J. "Knowledge management for manufacturing: the product and process database". Journal of Manufacturing Technology Management, vol. 15(7), pp. 575-584, 2004.

7. Nery-Kjerfve, T., \& McLean, G. N. "Repatriation of expatriate employees, knowledge transfer, and organizational learning: What do we know?", European Journal of Training and Development, vol. 36(6), pp. 614-629, 2012.

8. Alavi, M., \& Leidner, D. E. "Knowledge management and knowledge management systems: Conceptual foundations and research issues". MIS quarterly, pp. 107-136, 2010.

9. Duan, Y., Nie, W., \& Coakes, E. "Identifying key factors affecting transnational knowledge transfer". Information \& management, vol. 47(7-8), pp. 356-363, 2010. 
10. Schomaker, M. S., \& Zaheer, S. "The role of language in knowledge transfer to geographically dispersed manufacturing operations". Journal of International Management, vol. 20(1), pp. 55-72, 2014.

11. Shokri-Ghasabeh, M., \& Chileshe, N. "Knowledge management: Barriers to capturing lessons learned from Australian construction contractors perspective". Construction Innovation, vol. 14(1), pp.108-134, 2014.

12. Broekel T, Boschma R. "Knowledge networks in the Dutch aviation industry: the proximity paradox", J Econ Geogr, vol. 12, pp. 409-433, 2012.

13. Koskinen, K., Pihlanto, P. "Knowledge Management in Project-based Companies", An Organic Perspective. Palgrave Macmillan, New York, 2008.

14. Lindner, F., \& Wald, A., "Success factors of knowledge management in temporary organizations", International Journal of project management, vol. 29(7), pp. 877-888, 2011.

15. Ambos, T. C., \& Ambos, B., "The impact of distance on knowledge transfer effectiveness in multinational corporations". Journal of International Management, vol. 15(1), pp. 1-14, 2009.

16. Razmerita, L., Kirchner, K., \& Nielsen, P., "What factors influence knowledge sharing in organizations? A social dilemma perspective of social media communication", Journal of Knowledge Management, vol. 20, pp. 1225-1246, 2016.

17. Schilligo, J. A., "Predictors of effective knowledge management", ProQuest, 2007.

18. Wang, S., \& Noe, R. A., "Knowledge sharing: A review and directions for future research", Human resource management review, vol. 20(2), pp. 115-131, 2010.

19. Hofer, F., "Knowledge transfer between academia and industry", In Encyclopedia of Knowledge Management, Second Edition. pp. 977-986. IGI Global. 2011.

20. Easterby-Smith, M., Lyles, M. A., \& Tsang, E. W, "Inter-organizational knowledge transfer: Current themes and future prospects". Journal of management studies, vol. 45(4), pp. 677-690, 2008.

21. Rose, K. H. "A Guide to the Project Management Body of Knowledge (PMBOK® Guide)—Fifth Edition", Project management journal, vol. 44(3).

22. Govindarajan, V., \& Gupta, A. K., "Building an effective global business team", MIT Sloan Management Review, vol. 42(4), pp. 63, 2001.

23. Adenfelt, M., "Exploring the performance of transnational projects: shared knowledge, coordination and communication". International Journal of Project Management, vol. 28(6), pp. 529-538, 2010.

24. Mei, C., Tiexin, C., \& Hongqin, W., "A context-based model of knowledge transferring in project management", IEEE International Conference on Grey Systems and Intelligent Services, GSIS 2007. pp. 1465-1469, 2007.

25. Sandelowski, M. \& Barroso, J., "Handbook for synthesizing qualitativeresearch". Springer Publishing Company, 2007.

26. Karanjam, S. S., Karanjam, S., \& Sanaiey, N. Z., "Designing a Comprehensive Organizational E-Learning Model Using the Meta-Synthesis Method. Interdisciplinary", Journal of Virtual Learning in Medical Sciences, vol. 8(3), 2017.

27. Dawes, S. S., Gharawi, M. A., \& Burke, G. B., "Transnational public sector knowledge networks: Knowledge and information sharing in a multi-dimensional context", Government Information Quarterly, vol. 29, pp. 112-120, 2012.

28. Adenfelt, M., \& Lagerström, K., "Enabling knowledge creation and sharing in transnational projects", International journal of project management, vol. 24(3), pp. 191-198, 2006. 
29. Makela, K., Kalla, H. K., \& Piekkari, R., "Interpersonal similarity as a driver of knowledge sharing within multinational corporations", International Business Review, vol. 16(1), pp. 1-22, 2007.

30. Jasimuddin, S. M., Li, J., \& Perdikis, N., "Linkage between geographic space and knowledge transfer by multinational enterprises: a structural equation approach", The Annals of Regional Science, vol. 54(3), pp. 769-795, 2015.

31. Bengoa, D. S., Czinkota, M. R., Kaufmann, H. R., \& Schrader, M. F., "A concerted effort to transfer knowledge within European MNCs", European Journal of International Management, vol. 9(3), pp. 288-305, 2015.

32. Pérez-Nordtvedt, L., Kedia, B. L., Datta, D. K., \& Rasheed, A. A., "Effectiveness and efficiency of cross-border knowledge transfer: An empirical examination", Journal of management Studies, vol. 45(4), pp. 714-744, 2008.

33. Fletcher-Chen, C., "Impact of language diversity and social interaction on knowledge transfer", US-China Education Review, vol. 5(3), pp. 159-180, 2015.

34. Ford, D. P., \& Chan, Y. E., "Knowledge sharing in a multi-cultural setting: a case study", Knowledge Management Research \& Practice, vol. 1(1), pp. 11-27, 2003.

35. Ahmad, F., "Knowledge sharing in a non-native language context: Challenges and strategies", Journal of Information Science, 2017.

36. Fong Boh, W., Nguyen, T. T., \& Xu, Y., "Knowledge transfer across dissimilar cultures", Journal of Knowledge Management, vol. 17(1), pp. 29-46, 2013.

37. Ismail, M., Sobri, S. S., Zulkifly, N. A., Hamzah, S. R. A., \& Yamato, E., "Knowledge Transfer between Expatriates And Host Country Nationals: Contribution Of Individual And Social Capital Factors", Organizations and Markets in Emerging Economies, vol. 7(2), pp. 65-87, 2016.

38. Dobrai, K., Farkas, F., Karoliny, Z., \& Poór, J., "Knowledge transfer in multinational companies-evidence from Hungary", Acta Polytechnica Hungarica, vol. 9(3), pp. 149-161, 2012.

39. Ordóñez de Pablos, P., "Transnational corporations and strategic challenges: An analysis of knowledge flows and competitive advantage", The Learning Organization, vol. 13(6), pp. 544-559, 2006.

40. Killingsworth, B., Xue, Y., \& Liu, Y., "Factors influencing knowledge sharing among global virtual teams", Team Performance Management, vol. 22(5/6), pp. 84-300, 2016.

41. Vuori, V., \& Okkonen, J., "Knowledge sharing motivational factors of using an intra-organizational social media platform", Journal of knowledge management, vol. 16(4), pp. 592-603, 2012.

42. Sunaoshi, Y., Kotabe, M., \& Murray, J. Y. (2005). How technology transfer really occurs on the factory floor: a case of a major Japanese automotive die manufacturer in the United States. Journal of World Business, 40(1), 57-70.

43. Kayes, A. B., Kayes, D. C., \& Yamazaki, Y. (2005). Transferring knowledge across cultures: A learning competencies approach. Performance Improvement Quarterly, 18(4), 87-100.

44. Welch, D. E., \& Welch, L. S., "The importance of language in international knowledge transfer", Management International Review, vol. 48(3), pp. 339-360, 2008.

45. Gang, Q., \& Bosen, L., "Research on model of knowledge transfer in outsourced software projects", IEEE International Conference on E-Business and E-Government (ICEE), pp. 1894-1899, 2010.

46. Raab, K. J., Ambos, B., \& Tallman, S., "Strong or invisible hands?-Managerial involvement in the knowledge sharing process of globally dispersed knowledge groups", Journal of World Business, vol. 49(1), pp. 32-41, 2014. 
47. Hansen, M. T., \& Løvås, B. (2004). How do multinational companies leverage technological competencies? Moving from single to interdependent explanations. Strategic Management Journal, 25(8-9), 801-822.

48. Jonsson, A., \& Kalling, T. (2007). Challenges to knowledge sharing across national and intraorganizational boundaries: case studies of IKEA and SCA Packaging. Knowledge Management Research \& Practice, 5(3), 161-172.

49. Chen, C. J., Huang, J. W., \& Hsiao, Y. C. (2010). Knowledge management and innovativeness: The role of organizational climate and structure. International Journal of Manpower, 31(8), 848-870. 